\title{
A data archive of GPS navigation messages
}

\author{
G. Beyerle $\cdot$ M. Ramatschi $\cdot$ R. Galas $\cdot$ T. Schmidt . \\ J. Wickert $\cdot$ M. Rothacher
}

Published online: 21 August 2009

(C) Springer-Verlag 2009

\section{Erratum to: GPS Solut (2009) 13:35-41 \\ DOI 10.1007/s10291-008-0095-y}

The fourth sentence in section 'Subframe multiplicities' (Page 39) should read: 49\% (43,006,299 out of 88,099,200 subframes) were observed concurrently with at least two receivers $(M \geq 2)$.

We thank Tran Hoang Ha for bringing this error to our attention.

The online version of the original article can be found under doi:10.1007/s10291-008-0095-y.

G. Beyerle $(\bowtie) \cdot$ M. Ramatschi - R. Galas - T. Schmidt .

J. Wickert - M. Rothacher

GeoForschungsZentrum (GFZ), Potsdam, Germany

e-mail: gbeyerle@gfz-potsdam.de 